\title{
Project-Based Activity: Root of Research and Creative Thinking
}

\author{
Rambely, A. S. ${ }^{1}$, Ahmad, R. R. ${ }^{1}$, Majid N. ${ }^{1}$, M-Suradi, N. R. ${ }^{1}$, Din, U. K. S. ${ }^{1}$, A-Rahman, I. ${ }^{1}$, Mohamed, F. ${ }^{1}$, \\ Rahim, F. ${ }^{1} \&$ Abu-Hanifah, S. ${ }^{1}$ \\ ${ }^{1}$ Faculty of Science and Technology, Universiti Kebangsaan Malaysia, Selangor, Malaysia \\ Correspondence: Rambely, A. S., Faculty of Science and Technology, Universiti Kebangsaan Malaysia, 43600 \\ UKM Bangi, Selangor, Malaysia. Tel: 60-389-213-244. E-mail: asr@ukm.my
}

Received: February 7, $2013 \quad$ Accepted: February 28, $2013 \quad$ Online Published: April 25, 2013
$\begin{aligned} & \text { doi:10.5539/ies.v6n6p66 } \\ & \text { URL: http://dx.doi.org/10.5539/ies.v6n6p66 }\end{aligned}$

\begin{abstract}
Decreasing of interest in mathematics and science subjects among students in Malaysia has been discussed lately. Applications of mathematics and science in real world settings might be able to facilitate increased interests in the subjects, especially in doing research. Therefore, the aim of this paper is to manifest that learning mathematics through project-based activity would cultivate interest in students towards research and foster research-like skill. Experience of teaching mathematics in School of Mathematical Sciences, UKM with integration of biological and physics problems are discussed. The level of interest is measured through students' interest in doing their research projects in the final semester of the undergraduate study. The percentage of students interested in doing applied problems showed an increased in number. Thus it is concluded that the project-based activity led the students to identify their interest and hence head their interest into research.
\end{abstract}

Keywords: undergraduate research, motivations, student centered learning

\section{Introduction}

Nowadays, a higher education system all around the world is experiencing a transformation from a traditional one-way teaching method to the so called 'innovative' teaching method through student centered learning. The term 'innovative' is often used when we speak about new pedagogical methods and creative educators who represent a deviation from traditional didactics (Körös-Mikis, 2001).

Student centered learning is viewed as 'a concept of the student's choice in their education; others see it as the being about the student doing more than the lecturer (active versus passive learning); while others have a much broader definition which includes both of these concepts but, in addition, describes the shift in the power relationship between the student and the teacher (O'Neill \& McMahon, 2005). Brandes and Ginnis (1986) present the main principles of student-centred learning as:

- The learner has full responsibility for her/his learning

- Involvement and participation are necessary for learning

- The relationship between learners is more equal, promoting growth, development

- The teacher becomes a facilitator and resource person

- The learner experiences confluence in his education (affective and cognitive domains flow together)

- The learner sees himself differently as a result of the learning experience.

Many researchers have implemented student centered approach in the process of teaching and learning (Michelsen \& Sriraman, 2009; O'Neill \& McMahon, 2005; Halverscheid, 2005; Lew \& Schmidt, 2011; Blomqvist, Handberg \& Naeve, 2003; Graham, Tripp, Seawright \& Joeckel, 2007; Rambely \& Paijan, 2012). However, very few of them come from mathematics field. Some of the researchers who have applied student centered learning approach in mathematics field are Michelsen and Sriraman (2009), Picher (2006), and Rambely and Paijan (2012).

Current curricula in Malaysia tend to isolate or teaching mathematics without showing the importance in the real world. This bored the students because they cannot see the application of what they learn especially in mathematics subject, thus they lack of understanding of the subject. To prepare students with future life or excel in life, an interdisciplinary aspect must be included, for example mathematics with biological problems or 
mathematics with physics. Michelsen and Sriraman (2009) suggested that student activities centered on applications of mathematics and science in real world settings is able to facilitate increased interests in the subjects. Therefore, the aim of this paper is to show that learning mathematics through project-based activity would foster research-like skill and cultivate interest in students towards research.

\section{Methodology}

Project-based activity is a project develops naturally from regular chapters in class. An overview of the problem is given and students are free to decide the theme of the finding but few guided questions are given to stir the discussion and to start the research activity. This activity should minimize lecturer's guidance of the students. Students are divided into groups, which consists of multi-racial ethnicity and gender. The maximum number of students in a group is five. Some activities are observed and recorded using a video-camera. Students are free to come and ask questions to the lecturers should the need arises. At the end of the projects, each group is required to write and submit a report following the UKM style format and present their findings in class.

Here are some experiences collected from the project-based activity.

Case 1: For example, biology students who learnt chapters on exponential function were able to predict a population of human or animal. The student were asked to find a population data from the library and by using Microsoft excel they have to estimate the growth of a population and discovered the capacity parameter. A creative group cultured a kind of bacteria in a laboratory and recorded the growth of the bacteria population for the first few days. Later they proceeded with prediction of the population and discovered the capacity rate based on the cultured population.

Case 2: Students learnt mathematical concepts through captured human activity by video and observed though a Quicktime Movie Player. They were asked to describe a motion as a function of time. In the activity, they were required to analyze a video capture of a long jump activity, which was recorded in 15 frames per second and covered a time interval of 0.067 seconds between each frame. From the video capture, they have to find displacements and determine velocity and acceleration data from the performed activity.

From displacement data, derivations of instantaneous velocity and acceleration were performed using a central difference method. For example, an instantaneous velocity in the $\mathrm{x}$-direction $\left(v_{x}\right)$ of frame $\mathrm{i}$,

$$
v_{x i}=\frac{x_{(i+1)}-x_{(i-1)}}{t_{(i+1)}-t_{(i-1)}},
$$

where $x(i+1)$ and $x(i-1)$ are displacement of $x$ for frames $i+1$ (= a frame in the future) and $i-1$ (= a frame in the past). The $t(i+1)$ and $t(i-1)$ are corresponding times for frames $i+1$ and $i-1$.

In this activity, students were needed to investigate the data analyzed and think of few posed problems, for example they had to determine how the horizontal and vertical velocities changes before a subject takes off and determine the highest peak of accelerated direction after taking off. In the report, students managed to include some points in the discussion for example, the changes of velocity components while subject was in airborne phase, acceleration components for the center of body during the airborne phase, and behavior of braking movement during a landing phase.

Case 3: A projectile motion was studied for two different activities. The first was a football kick, where a motion of an object starts from the ground. The motion from the ground is the simplest example to be analyzed. The final motion depends on only velocity component of an object at the take-off point. Thus students were asked to determine the horizontal and vertical velocity components of the football when it was kicked from the ground. The second activity is a shot put throw, where the motion of an object starts from a certain height. The motion of shot put throw are determined by the velocity (speed and angle) and the take-off height after the object was released from the subject. They manipulated the distance equation to find the total flight time, $t$,

$$
t_{\text {total }}=\frac{-v_{y} \pm \sqrt{v_{y}^{2}-2 g h}}{g}
$$

where $v_{y}$ is the initial vertical velocity, $g$ is the acceleration due to gravity $\left(=-9.81 \mathrm{~ms}^{-2}\right)$, and $h$ is the height of release. 
In this projectile motion activity, students included the discussion on the relationship between time of flight, flight distance and maximum flight height. They also discussed the relationship between optimal angles and velocity of an object at release and the effect of height when the object was release with the optimum angles.

Based on the previous cases discussed, a short survey was conducted on mathematical sciences students taking a scientific research course in the final semester. The final year research project dissertation which is offered to the final year students aims to train the students to undertake a self-learning process with closed supervision on an extended or new topic in mathematical sciences area. A survey using questionnaires was carried out on 136 final year students from the School of Mathematical Sciences.

In this study, the perspectives of the students regarding feedback of the final year research project were collected. The intention is to look at motivation of students towards a final year research project which is believed to be cultivated from the project-based activities. Factor analysis using oblimin rotation and frequency based on factors were done. Factor analysis was conducted on the research data to identify groupings of the items. The items were grouped into three categories. Only one category which is motivational factors towards the research project is discussed.

\section{Results and Discussions}

The data of project done in the final year research project were taken on normal semester, which is the sixth or the last semester of student candidature. Students normally take the final year project paper in their second semester of the third year study. Records from the Mathematics Program, School of Mathematical Sciences, Faculty of Science and Technology, Universiti Kebangsaan Malaysia showed that an increased interest towards doing a final research project with an applied mathematics problems and mechanics based problems as illustrated in Table 1. Based on project-based activity done in class of mechanics, students are prone to come out with topics related to mechanics regardless of supervisors' interests or fields. Students were able to suggest a research topic related to their interest and proceed with the research.

Table 1. Number of Mathematics major students doing final year project

\begin{tabular}{lcccccccc}
\hline Semester/Session & \multicolumn{2}{c}{$2 / 0809$} & \multicolumn{2}{c}{$2 / 0910$} & \multicolumn{2}{c}{$2 / 1011$} & \multicolumn{2}{c}{$2 / 1112$} \\
$\mathrm{~N}$ & 80 & $\%$ & 73 & $\%$ & 68 & $\%$ & 23 & $\%$ \\
\hline Applied research & 35 & 43.8 & 25 & 34.2 & 27 & 39.7 & 12 & 52.2 \\
Mechanics problems & 6 & 7.5 & 9 & 12.3 & 10 & 14.7 & 3 & 13.0 \\
Enrichment of mathematics & 17 & 21.3 & 16 & 21.9 & 10 & 14.7 & 4 & 17.4 \\
Pure research & 21 & 26.3 & 23 & 31.5 & 21 & 30.9 & 4 & 17.4 \\
Educational research & 1 & 1.3 & 0 & 0.0 & 0 & 0.0 & 0 & 0.0 \\
\hline
\end{tabular}

From Table 1, data illustrated that number of students doing applied mathematics and mechanics related researches were increasing. However, pure mathematics research which involved proving axioms and theorems, mathematical inductions and deductions decreased in number. The factor loadings representing students' perspectives towards the research projects using oblimin rotation are presented in Table 2.

Table 2. Motivational factor towards final year research project

\begin{tabular}{lll}
\hline & Item & Factor \\
\hline P1 & Final year research project helps my self-development & 0.915 \\
P2 & Final year research project cultivates lifelong learning & 0.899 \\
P3 & Final year research project increases self confidence & 0.845 \\
P4 & Final year research project improves my dedication towards my & 0.929 \\
& work & 0.833 \\
P5 & Final year research project improves self discipline & 0.721 \\
P6 & Final year research project improves my time management skill & 0.850 \\
P7 & Final year research project helps self-learning skill & 0.680 \\
P8 & Final year research project helps improve my problem solving skill & 0.523 \\
P10 & Final year research project provides exposure to research &
\end{tabular}


P12 Final year research project generates new knowledge

Reliability Coefficient of Motivational Factor $=0.957$

Eleven out of 22 items were identified as motivational factors with loadings ranging from 0.41 to 0.93 (Rokiah et al. 2011). It is strongly believed that the project-based activities have successfully cultivated the three items, which are P10, P12 and P20. In addition, students reported that the final year research training profoundly contributed to their self-skill development, as shown in items P1 to P8. Further analysis was carried out to identify the most and least impactful items using the mean scores, as shown in Table 3 . The item with the highest mean score was 'Final year project generates new knowledge' (mean $=6.12)$, while the item with the lowest mean score was 'Final year project helps me with my self-development' $($ mean $=5.85)$.

Table 3. Highest and lowest mean values for motivational factor

\begin{tabular}{ll}
\hline Item & Mean Value \\
\hline Final year research project helps my self-development & 5.85 \\
Final year research project generates new knowledge & 6.12 \\
\hline
\end{tabular}

It can be observed that everyday activities done and discussed as class projects were able to trigger their creativity and encourage them to embark in a small research naturally. Thus, through project-based activity, a student might realize their interest, or opening up their mind tailoring to their interest. Majid et al. (2012) stated that research project provides the opportunity to students in applying the knowledge learned from previous courses to produce a quality research through guided self-learning. For example, topics that had been done in the previous semesters of the final year research projects were trajectory of an angry bird (in computer games), conversion in rugby, angular momentum of an American-Jive dancing which used the concept of mechanics. According to Michelsen and Sriraman (2009), the overall implication of the literature in interest research is that situational interest can facilitate cognitive processing and improve students' learning.

Based on Table 4, the motivational factor shows that majority of the respondents (more than $90 \%$ ) agreed in all items in terms of the benefits or impact of research project. Item 'research project generates new knowledge' received the highest percentage of agreement of $97.8 \%$. Item 'research project improves self-discipline' and 'research project improves self-learning skill' recorded the second highest percentage with $95.6 \%$ respondents.

Table 4. Percentage of agreement based on motivational factor

\begin{tabular}{lllll}
\hline Item & & $\begin{array}{l}\text { Disagree } \\
(\%)\end{array}$ & $\begin{array}{c}\text { Not Sure } \\
(\%)\end{array}$ & $\begin{array}{l}\text { Agree } \\
(\%)\end{array}$ \\
\hline P1 & $\begin{array}{l}\text { Final year research project helps my } \\
\text { self-development }\end{array}$ & $\mathbf{0 . 7}$ & $\mathbf{8 . 1}$ & $\mathbf{9 1 . 2}$ \\
P2 & $\begin{array}{l}\text { Final year research project cultivates life-long } \\
\text { learning }\end{array}$ & 0.7 & 7.4 & $\mathbf{9 1 . 9}$ \\
P3 & $\begin{array}{l}\text { Final year research project increases self } \\
\text { confidence }\end{array}$ & 0.7 & 5.9 & $\mathbf{9 3 . 4}$ \\
P4 & $\begin{array}{l}\text { Final year research project improves my } \\
\text { dedication towards my work }\end{array}$ & 0.7 & 5.1 & $\mathbf{9 4 . 1}$ \\
P5 & $\begin{array}{l}\text { Final year research project improves self } \\
\text { discipline }\end{array}$ & 1.5 & 2.9 & $\mathbf{9 5 . 6}$ \\
P6 & $\begin{array}{l}\text { Final year research project improves my time } \\
\text { management skill }\end{array}$ & 0.7 & 5.9 & $\mathbf{9 3 . 4}$ \\
P7 & $\begin{array}{l}\text { Final year research project helps self-learning } \\
\text { skill }\end{array}$ & 0 & 4.4 & $\mathbf{9 5 . 6}$ \\
P8 & $\begin{array}{l}\text { Final year research project helps improve my } \\
\text { problem solving skill }\end{array}$ & 0 & 5.9 & $\mathbf{9 4 . 1}$ \\
P10 & Final year research project provides exposure to & 0 & 5.1 & $\mathbf{9 4 . 1}$
\end{tabular}


research

P12 Final year research project generates new knowledge

P20 Final year research project improves my creative thinking skill

\section{Changes in Methods of Learning}

An educator should be able to play a role in nurturing the research skill and developing inquisitive mind that move towards research. Through a project-based activity, it led the students to identify their interest and hence head their interest into research. Middleton (1995) showed that the better teachers were at anticipating the motivational structures of their students, the better they were at providing an environment that facilitated the development of intrinsic motivation.

Schiefele (1991) defines interest as a relatively long-term orientation of a person towards an object or an activity. Interest is thus conceptualized as a relational construct between a person and an object (Michelsen \& Sriraman, 2009). The object can be a topic, an idea or other life-space. But how do we (the educators or lecturers) make the students to identify their interest in order to pursue their research interest? We have to relate them with their experience and previous knowledge based on their personal interest supported by their strength in the mathematical field. This will lead to seeding of research experience where student is able to propose their research topics based on learnt experience.

Innovation can be established in any phase of teaching or learning process. Those defining it unanimously agreed that combining innovative practice and teacher-centred approaches to teaching can only be done with great difficulty, or not at all. Innovative teaching and learning processes are most often characterised by group exercises, teamwork or individual study. In this study, the emphasis is on learning rather than teaching. Exercises in this context mostly take the form of experimental research projects designed to maintain students' curiosity, and also providing long-term motivation to search for solutions independently. Furthermore, most students are found to welcome the challenge of taking on for themselves the responsibility for managing their own learning, using their lecturers as 'learning resources' as and when required. Thus through student activities centered on applications of mathematics and science in real world settings are able to facilitate increased interests in the subjects, and hence foster research-like skill and cultivate interest in students towards research.

\section{Conclusions}

This paper discusses an experience run in class through project-based activity in the form of small experimental research projects in the School of Mathematical Sciences. The relation of performing class project activities and final year research projects are observed as a measure of student interest in doing research. The authors do not claim that the project-based activity does reflect the chosen final year project, but somehow the project-based activities do open up students' interest in performing their final year research project. The findings conclude that an educator should be able to play a role in nurturing the research skill and developing inquisitive mind that move towards research. Finally, the project-based activity led the students to identify their interest and hence head their interest into research.

\section{Acknowledgement}

The authors would like to acknowledge the research grants PTS-2011-042, PTS-2012-076 and UKM-PTS-011-2010.

\section{References}

Blomqvist, U., Handberg, L., \& Naeve, A. (2003). New Methods for focusing on Students' Learning Process and Reflection in Higher Education. Proceedings of the 28th IUT (Improving University Teaching) Conference, Växjö, Sweden. ISSN 1403-0721.

Brandes, D., \& P. Ginnis. (1986). A Guide to Student Centred Learning. Oxford: Blackwell.

Graham, C. R., Tripp, T. R., Seawright, L., \& Joeckel, G. (2007). Empowering or compelling reluctant participators using audience response systems. Active Learning in Higher Education, 8, 233. http://dx.doi.org/10.1177/1469787407081885

Körös-Mikis, M. (2001). Defining Innovative Pedagogical Practice by LOGO-educators. Proceedings of the $8^{\text {th }}$ European Logo Conference, 21-25 August, Linz, Austria. Retrieved from http://www.ocg.at/activities/books/ volumes/ band\%20156/P63koros.doc 
Lew, M. D. N., \& Schmidt, H. G. (2011). Self-reflection and academic performance: Is there a relationship? Adv in Health Sci Educ, 16, 529-545. http://dx.doi.org/10.1007/s10459-011-9298-z

Noriza Majid, Rokiah, Rozita Ahmad, Ummul Khair Salma Din, Azmin Sham Rambely, Nur Riza Mohd Suradi, \& Faridatul Azna Ahmad Shahabudin. (2012). Academic Research Process: A Review on Current Practices in School of Mathematical Sciences. Procedia - Social and Behavioral Sciences, 59, 394-398. http://dx.doi.org/10.1016/j.sbspro.2012.09.292

Michelsen, C., \& Sriraman, B. (2009). Does interdisciplinary instruction raise students' interest in mathematics and the subjects of the natural science? ZDM Mathematics Education, 41, 231-244. http://dx.doi.org/10.1007/s11858-008-0161-5

Middleton, J. A. (1995). A study of intrinsic motivation in the mathematics classroom: A personal constructs approach. Journal for Research in Mathematics Education, 26, 254-279. http://dx.doi.org/10.2307/749130

O’Neill, G., \& McMahon, T. (2005). Student-centred learning: What does it mean for students and lecturers? Emerging Issues in the Practice of University Learning and Teaching. All Ireland Society for Higher Education. Retrieved from http://www.aishe.org/readings/2005-1/oneill-mcmahon Tues_19th_Oct_SCL. html\#XLea2003.

Picher, F. (2006). Social Reflection in Mathematics Classes: Cooperation or Denial. ZDM Analyses, 38(4), 333-340. ISSN 1615-679X.

Rambely, A. S. \& Paijan, F. (2012). Transformation of mathematics learning: Taman Paku-Pakis as a learning laboratory. Procedia - Social and Behavioral Sciences, 59, 150-156. http://dx.doi.org/10.1016/j.sbspro.2012.09.259

Rokiah Rozita Ahmad, Nur Riza Mohd Suradi, Noriza Majid, Faridatulazna Ahmad Shahabuddin, Azmin Sham Rambely, Ummul Khair Salma Din, \& Zalina Mohd Ali. (2011). The Role of Final Year Project in The School of Mathematical Sciences in Human Capital Development. Procedia - Social and Behavioral Sciences, 18, 450-459. http://dx.doi.org/10.1016/j.sbspro.2011.05.066

Schiefele, U. (1991). Interest, learning and motivation. Educational Psychologist, 26(3-4), 299-323. http://dx.doi.org/10.1080/00461520.1991.9653136 